УДК 61:007:002.6:681.31:616.72-007-07-08

\title{
ПРОБЛЕМИ ДІАГНОСТИКИ І ЛІКУВАННЯ АРТРОЗУ: ІНФОРМАЦІЙНІ АСПЕКТИ I ВИСНОВКИ
}

\author{
Національний університет фозичного виховання і спорту України

\begin{abstract}
Розглянуто питання інтегрального оцінювання клініки остеоартрозу з точки зору кількісної оцінки тяжкості стану хворих, прогнозування результатів лікування, вибору періоду при моніторингу стану пацієнтів, коли оперативне лікування дає найкращі результати.
\end{abstract}

Ключові слова: діагностика та лікування остеоартрозу; інформаційні технології в лікуванні остеоартрозу, проблеми індивідуалізації лікування хворих на гонартроз; прогнозування результатів лікування остеоартрозу.

\section{ПРОБЛЕМЫ ДИАГНОСТИКИ И ЛЕЧЕНИЯ АРТРОЗА: ИНФОРМАЦИОННЫЕ АСПЕКТЫ И ВЫВОДЫ}

\author{
М. М. Риган \\ Национальный университет фризического воспитания и спорта Украины
}

\begin{abstract}
Рассмотрены вопросы интегральной оценки клиники остеоартроза с точки зрения количественной оценки тяжести состояния больных, прогнозирования исходов лечения, выбора периода при мониторинге состояния пациентов, когда оперативное лечение дает наилучшие результаты.
\end{abstract}

Ключевые слова: диагностика и лечение остеоартроза; информационные технологии в лечении остеоартроза, проблемы индивидуализации лечения больных на гонартроз; прогнозирование результатов лечения остеоартроза.

\section{THE DIAGNOSTICS AND TREATMENT PROBLEMS OF ARTHROSIS: INFORMATIVE ASPECTS AND CONCLUSIONS}

M.M. Ryhan

\section{National University of Physical Education and Sport of Ukraine}

\begin{abstract}
There were considered the problems of integrated assessment clinic osteoarthritis in terms of quantifying the severity of
\end{abstract} patients, predicting treatment outcomes, selecting a period in the monitoring of patients when surgery gives the best results.

\begin{abstract}
Key words: the diagnostics and treatment of osteoarthrosis; information technologies in osteoarthrosis treatment, the individualization problems of gonartrosis patient treatment, predicton results of osteoarthrosis treatment.
\end{abstract}

Вступ. Одним з найпоширеніших захворювань, яке уражає до $10 \%$ в популяції в усьому світі, є остеоартроз. Частота цієї патології серед усіх ортопедичних захворювань, 3 приводу яких пацієнти звертаються до лікаря, коливається від 30 до $55 \%[1,2]$. Остеартроз представляє гетерогенну групу захворювань різної етіології, але з подібними біологічними, морфологічними та клінічними проявами та результатом. В основі їх лежить ураження всіх компонентів суглоба, насамперед, хряща, а також субхондральної кістки, синовіальної оболонки, зв'язок, капсули і периартикулярних м'язів [1].
За даними літератури, проблема ефективного лікування гонартрозу має не тільки медико -соціальне. але й економічне значення.

Не зважаючи на пильну увагу до патології серед фахівців і достатньо довгий досвід спостережень, недостатня вивченість етіології та патогенезу дегенеративних захворювань суглобів, пізня діагностика, різноманіття варіантів прояву та перебігу, ускладнення - все це значно ускладнює вибір адекватного лікування [5].

На практиці пацієнту з гонартрозом пропонують стандартну схему лікування, яка включає нестероїдні протизапальні препарати, тривалий прийом симптом-

(c) М. М. Риган 
модифікувальних препаратів - хондропротекторів [6, 8]. У ряді випадків при супутніх захворюваннях пацієнту призначають селективні інгібітори циклооксигенази (ЦОГ) -2, а при нестримному болю в колінному суглобі проводять внутрішньосуглобове введення глюкокортикостероїдів (ГКС).

Важливо підкреслити, що системного підходу до лікування хворих на остеоартроз не існує. Сучасні підходи до лікування спрямовані на зменшення патологічної симптоматики за допомогою різних методів:

- не фармакологічне лікування (фізичні вправи, зміна способу життя);

- фармакологічне лікування (нестероідні протизапальні препарати НПЗП, місцеве лікування);

- інвазивні методи лікування (внутрішньосуглобові ін'єкції, артроскопія, артропластика).

Звісно, лікування хворих з дегенеративними захворюваннями суглобів має бути раннім, патогенетичним, комплексним і етапним. Однак все це існує на концептуальному рівні. Алгоритмічної складової в лікуванні остеартрозу не існує.

Мета роботи - узагальнення наявних даних щодо стратегії ранньої діагностики та формулювання глобальної стратегії лікування на основі інформаційних технологій.

Результати та їх обговорення. Якщо розглядати патогенетичні механізми, то за сучасними уявленнями в основі розвитку остеартрозу лежить порушення динамічної рівноваги між анаболічними i катаболічними процесами в суглобовому хрящі. Вважають, що при патологічних станах зростає інтенсивність катаболізму хряща, що перевищує активність анаболічних процесів. Біохімічні та метаболічні зміни суглобового хряща призводять до погіршення його біомеханічних властивостей, що негативно впливає на субхондральну кістку, викликаючи порушення кісткового балансу, підвищення внутрішньокісткового тиску і розвиток субхондрального склерозу і остеофітів [1].

Якщо прийняти подібну концепцію, то терапевтичний вплив повинен бути спрямований на сисгемоутворювальну компоненту патологічного процесу і локальну компоненту, спрямовану на симптоматичну дію.

Локальна компонента пов'язана із застосуванням нестероїдних протизапальних лікарських засобів (НПЛ3), які зменшують больовий синдром і прояв запалення в суглобах. Основним недоліком НПЛЗ є частий розвиток побічних ефектів, особливо з боку шлунково-кишкового тракту та серцево-судинної системи [5]. Більше того, деякі з них негативно впливають на метаболізм суглобового хряща.
Застосування препаратів, потенційно здатних модифікувати обмінні процеси в хрящі, привертає увагу насамперед через безпечність при лікуванні. Вони характеризуються, 3 одного боку, порівнянною 3 НПЛЗ дією на біль і функцію суглобів, з іншого деякими хондропротекторними властивостями і здатністю впливати на перебіг захворювання і його результат.

Ефективність перорального застосування хондроїтину сульфату (ХC) і глюкозаміну (ГА) у лікуванні гонартрозу була доведена рядом експериментальних і клінічних досліджень, в яких проводилася оцінка як симптоматичного ефекту цих препаратів, так i рентгенологічної прогресії захворювання на тлі їх застосування $[7,8]$.

Інші автори вважають оптимальною локальну терапію, оскільки при внутрішньосуглобовому введенні ефект препаратів максимальний [6].

Важливо забезпечити порівняння діагностичної цінності різних методів дослідження, включаючи рентгенографію, ультразвукове дослідження, магнітнорезонансну томографію та артроскопію для з'ясування причини больового синдрому в колінному суглобі.

При цьому важливо оцінити статистичну валідність методів, в тому числі (або принаймні) чутливість i специфічність кожного із зазначених методів для виявлення ураження суглобового хряща, синовіїту і розривів менісків. На загальну думку, «золотим стандартом» слід вважати артроскопію, як метод прямої візуалізації тканин колінного суглоба. Саме він дозволяє візуалізувати всі внутрішньосуглобові структури і дає повну інформацію про ступінь і поширеність ураження суглобового хряща.

Ще одним важливим напрямком слід визнати повторюваність результатів досліджень (стійкість результатів) протягом певного часу.

За даними літератури і на нашу думку, настав період вироблення принципів індивідуалізованого підходу до вибору методів лікування остеоартрозу залежно від вираженості та тривалості больового синдрому й ступеня функціональних порушень. Вони, насамперед, повинні включати рекомендації щодо вибору методу локальної терапії, фізіотерапевтичного лікування та їх комплексного застосування в різних групах хворих на остеоартроз, залежно від вираженості та тривалості больового синдрому, ступеня функціональних порушень, динаміки функціонального стану колінного суглоба на тлі індивідуально підібраного комплексу лікувальних процедур.

Повинна бути розроблена система прогнозування розвитку патологічного процесу, створені стандартні 
схеми розрахунку прогностичних показників для визначення ефективності запропонованого виду локальної терапії або використання хірургічних методів. При цьому повинні застосовуватися обгрунтовані підходи перспективного прогнозування середніх величин показників артрологічному статусу, виходячи з віку i даних обстеження хворого (індексу маси тіла пацієнта, тривалості захворювання, ширини рентгенівської суглобової щілини та рівня больового синдрому тощо), інструментального обстеження, розрахункових показників (рівень болю за ВАШ, індекс WOMAC, індекс HAQ). Для практичного застосування важливо розробити алгоритми обстеження хворих на остеоартроз і шкали прогностичних показників для оцінки результатів лікування.

Зрозуміло, важливо обгрунтувати загальні принципи застосування НПЛЗ при шнартрозі, включаючи мінімально ефективні добові дози, оптимальні комбінації препаратів короткої і середньої дії (з періодом напіввиведення до 24 годин), i, нарешті, логіку застосування селективних інгібіторів ЦОГ-2 у пацієнтів 3 факторами ризику небажаної дії НПЛЗ.

Важливо оцінити ефективність використання гіалуронату [2]. Вивчення впливу гіалуронату натрію на синовіальну рідину і хрящову тканину показало, що він не тільки коригує метаболізм хряща, підвищуючи синтез власних протеогліканів, але і пригнічує синтез простагландинів, надаючи протизапальний ефект. Таким чином, здатність гіалуронової кислоти впливати на метаболізм хрящової тканини дозволяє віднести препарати, що містять іï, до засобів патогенетичної терапії остеоартрозу та гонартрозу зокрема [7,9].

Очевидно, що велика кількість випадків гонартрозу не обходиться без оперативного лікування. Найчастіше для лікування гонартрозу застосовують три основні методики оперативного втручання. Це артроскопія, коригуюча остеотомія та ендопротезування. Сьогодні артроскопічні операції при гонартрозі застосовують досить часто і включають в себе ряд методик - від ревізії та санації суглоба до застосування лазера, плазмової абляції, хондропластики. За даними літератури, ефективність артроскошї при проведенні елементарних процедур лаважу і дебрідмента становить $74 \%$ [10].

У найтяжчих випадках використовують і більш інвазивні методики - від коригуючої остеотомії до ендопротезування. Коригуюча остеотомія найефективніша і показана на початковому етапі порушення осьових параметрів кінцівки [4]. У запущених випадках, враховуючи весь комплекс медичних і соціальних факторів, крім ендопротезування іноді рекомендується артродез.

Ефективність тотальної артропластики колінного суглоба переконливо доведена у інвалідизованих пацієнтів 3 тяжким гонартрозом [1]. Артропластика колінного суглоба $є$ відносно безпечним і ефективним методом лікування, що забезпечує поліпшення якості життя, зменшення больового синдрому та збільшення функціональної рухливості суглоба. Хороші чи відмінні результати щодо зменшення больового синдрому та поліпшення функціональної рухливості протягом 5 років після проведення оперативного втручання відзначаються у майже 90 \% пацієнтів [9].

Схема сучасного підходу до лікування дегенеративно-дистрофічних захворювань колінного суглоба залежить, насамперед, від стадії захворювання. Однак при лікуванні пацієнтів з гонартрозом необхідно враховувати й інші показники: наявність факторів ризику для колінного суглоба (ожиріння, небажані механічні фактори, підвищена фізична активність); наявність загальних факторів ризику (вік, супутні захворювання, полімедикація); вираженість больового синдрому та функціональної недостатності суглоба; наявність ознак запалення (наприклад, випоту в суглобову порожнину); локалізацію і ступінь структурних пошкоджень і ще десятки інших факторів.

Все це робить завдання вибору терміну оперативного втручання, його обсягу та особливостей ведення післяопераційного періоду складним і недостатньо прогнозованим. Необхідні нові інформаційні підходи.

Висновки. 1. Стратегія лікування хворих на гонартроз обумовлюється численними факторами: стадією і виразністю захворювання, супутніми процесами тощо. Комплексний їх облік повинен проводитися на основі використання сучасних інформаційних методів і базуватися не тільки на об'єктивних методах дослідження, суб' єктивних відчуттях пацієнтів, але і критеріях їх прогностичної важливості.

2. Актуальними проблемами є обгрунтування принципів індивідуалізованого підходу, принципів моніторингу стану пацієнтів, оцінювання ризиків лікування. 


\section{Література}

1. Багирова Г. Г. Остеоартроз: эпидемиология, клиника, диагностика, лечение/Г. Г. Багирова. О. Ю. Мейко. - М, 2005.-224 c.

2. Бадокин В. В. Пути оптимизации терапии остеоартроза /В. В. Бадокин//РМЖ. -2006. - Т 14 . - № 5 . - С. 1824-1828. 3. Гейдешман Е. С. Выбор способа хирургического лечения больных с дефектами хряща коленного сустава при шнартрозе / Е. С. Еейдешман: автореф. дисс. к.м.н. Самара 2008.-23 с.

4. Григорян Б. С. Корригирующие операции в лечении шнартроза/Б. С. Еригорян: автореф. дисс. к.м.н. - М , 2003.-26 c.

5. Коршунов Н. И. Современные подходы к фармакотерапии остеоартроза / Н. И. Коршунов, О. Б. Ершова // Consilium medicum -2006. - №2 . - C. 34-38.

6. Лила А. М. Современная фармакотерапия остеоартро-
за/А. М. Лила//Terramedica. -2005. -№ 1 (37). - С. 3-9. 7. Пешехонова Л. К. Клиническая эффективность хондропротекгоров в комплексной терапии остеоартроза коленных суставов / Пешехонова Л. К., Кузовкина Т. Н,, Пешехонов Д. В. //РМЖ. -2009. - №21 . - С. 1486-1489.

8. Поворознюк В. В. Елюкозамин и хондроитин в лечении остеоартроза: данные литературы и результаты собственных исследований / В. В. Поворознюк // РМЖ. - 2006. T. 14. - № 4 . - C . 290-294.

9. Gapl M. Surgical treatment of the knee osteoarthritis / M. Gapl//Reumatizam -2005. - № 52 (2). - P. 52-55.

10. Oakley S. P. Acritical appraisal of quantitative arthroscopy as an outcome measure in osteoarthritis of the knee // S. P. Oakley, M. N. Lassere // Semin Arthritis Rheum - 2003. №33(2). -P. 83-105. 